\title{
Simply call him abuelo
}

Timothy D. McKinley, BS

Neurology ${ }^{\circledR}$ 2018;90:e623-e624. doi:10.1212/WNL.0000000000004948

The first day of February started like most winter Philadelphia mornings-cold, dark, and hurried. Rushing to the subway, heading to class as a first-year medical student, I quickly called my parents to check on them. After an overnight snowfall, they were driving from their home in central Pennsylvania to their beach bungalow on the Outer Banks.

Mom answered. She was waiting in the car at a gas station south of Harrisburg. Dad was taking a long time to come back from the bathroom. Groggy and tired after working a 24-hour shift at the hospital, he had slept most of the trip. Luckily, the roads were cleared and salted and they expected to make Hatteras by nightfall.

An hour later, I received a text from my mom asking if I had a moment to call. Lecture would be over at noon so I told her I'd call at lunch.

"Can you call now?"

Dad was in an ambulance. Moments earlier he noticed tingling and weakness in his left arm and had my mom pull to the side of the highway and call 911 . I told her to head to the hospital and I would contact my siblings.

My father is no stranger to tragedy. At 14, a transfusion-related acute lung injury left him vented in the ICU. His parish priest performed last rites. Despite his physicians' realistically dark expectations, he spent the next 2 weeks fighting back. When he was finally able to breathe on his own, he vowed to be the last child to receive a deathbed anointing of the sick.

Now 60 years old, my father has spent 4 decades aiming to fulfill that promise, working as a pediatric intensivist at a large regional hospital. Four of his 5 children followed his path into medicine. He continually demonstrates Ralph Waldo Emerson's assertion: "We acquire the strength we have overcome."

I called my brother Ken, a pediatrician in New York, and we drove together to Frederick, Maryland, along with his wife Monica and my fiancée Marissa. Hours later, on our frustratingly slow trip down I-95, we learned that my father had suffered a stroke but was doing well. The emergency physicians and neurologists had agreed to administer tPA when my father insisted the use of his nondominant hand was critical to continuing his life's work. He was now alert and had regained strength in his left arm.

Late that night, however, we arrived at Frederick Memorial to find a rapidly deteriorating situation. My somber father struggled as he described being "imprisoned" in the intensive care unit. He lay prostrate upon the bed, attached to a catheter, despondent. His left arm was extremely weak and his face severely sunken. The stroke's early resolution had all but reversed, and a significant hemiparesis had settled in. "He's a max assist," explained his bedside nurse, "he can't help me at all with his left side."

When my sister Rosie arrived from Durham, we gathered around my dad's bed. My mom had inquired about a priest, and he arrived to perform last rites, now the second time my dad had received the last breath sacrament. I looked to Marissa, and wondered if my father would live to see us married in July.

My dad asked us all to come close, as if to offer his final earthly thoughts. He looked at my sister and then at me, and said "abuelo." Suddenly I realized that the stroke had affected more than just his pyramidal tracts. This brilliant physician and sharp-witted father was now simply uttering an irrelevant term in another language. I assumed the worst; this was the onset of a delirium precipitated by a growing intracerebral hemorrhage. My sister and I traded horrified looks.

But then the entire dynamic changed literally in the blink of an eye.
Correspondence

Mr. McKinley

tuf70402@temple.edu

MORE ONLINE

\section{ค Audio}

Listen to Mr. McKinley

read this story.

NPub.org/h8m1qi 
My father winked at my beaming brother, who then announced, "Moni and I are expecting a child. Dad is going to be a grandfather, an abuelo!” Ken had told my parents just the night before that Monica, a native of Argentina, was pregnant. Dad's left side was almost completely paralyzed, his face drooped, legs and arms motionless. Amidst all this, his thoughts remained on his kids and their happiness. He smiled and closed his eyes.

My father survived the night. There was no hemorrhage. There were no cognitive impairments. There were, however, many physical therapy sessions, stumbles, falls, and disappointments as he struggled to overcome a diagnosis of leftsided spastic hemiplegia.

Support from the community poured in:

Dear Dr. McKinley,

Over the Easter weekend I heard the unfortunate news that you had a stroke. As a stroke survivor myself, I knew what you were experiencing and began praying for you. Keep up the good work and keep hope alive. You probably don't know my name but I'm sure you would recognize me. I'm the old lady with the cane who you often help going into church.

Sincerely,

M. Lloyd

Throughout his arduous recovery, my father vowed to walk by my wedding day and to hold his future grandchild in his arms. He progressed from a wheelchair, to crutches, a cane, and ever so slowly he began to walk.

In July, my father stood proudly as Marissa and I exchanged vows. A few weeks later, his first grandchild was born, and the baby fell asleep in his arms. Six months to the day from his stroke, after proving to himself and his colleagues he was again skilled with critical care procedures, Dr. McKinley confidently walked through the double doors of the intensive care unit and returned to his life's work. Some may see him as a stroke survivor. Others as an inspiration. $\mathrm{He}$ is grateful to see himself as always: a physician. My family and I see him as all these things, and one more. We simply call him abuelo. 


\section{Neurology}

\section{Simply call him abuelo}

Timothy D. McKinley

Neurology 2018;90;e623-e624

DOI 10.1212/WNL.0000000000004948

This information is current as of February 12, 2018

\section{Updated Information \&} Services

Subspecialty Collections

Permissions \& Licensing

Reprints including high resolution figures, can be found at: http://n.neurology.org/content/90/7/e623.full

This article, along with others on similar topics, appears in the following collection(s):

All Cerebrovascular disease/Stroke

http://n.neurology.org/cgi/collection/all_cerebrovascular_disease_strok e

Infarction

http://n.neurology.org/cgi/collection/infarction

Information about reproducing this article in parts (figures,tables) or in its entirety can be found online at:

http://www.neurology.org/about/about_the_journal\#permissions

Information about ordering reprints can be found online:

http://n.neurology.org/subscribers/advertise

Neurology ${ }^{\circledR}$ is the official journal of the American Academy of Neurology. Published continuously since 1951, it is now a weekly with 48 issues per year. Copyright () 2018 American Academy of Neurology. All rights reserved. Print ISSN: 0028-3878. Online ISSN: 1526-632X.

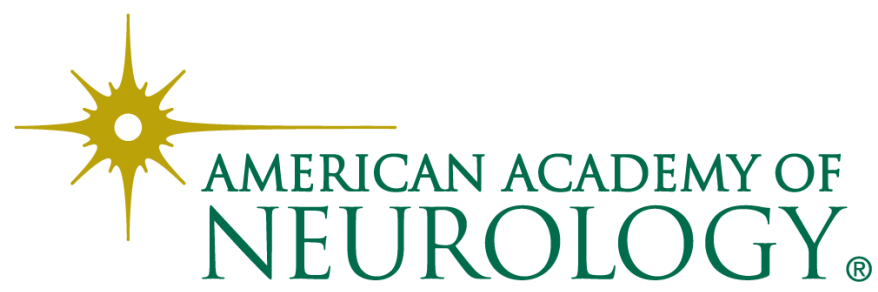

